\title{
Muslim Women and Everyday Environmentalism in Post-Covid Indonesia: Shifting the Canon?
}

\author{
June Cahyaningtyas ${ }^{1}$, Wening Udasmoro ${ }^{2}$, Dicky Sofjan ${ }^{3}$ \\ Inter-Religious Studies, Gadjah Mada University. International Relations, UPN Veteran \\ Yogyakarta $^{1}$, Faculty of Culture, Gadjah Mada University ${ }^{2}$, Inter-Religious Studies, Gadjah \\ Mada University ${ }^{3}$
}

\begin{abstract}
Everyday environmentalism in Indonesia is inseparable from the presence of some Muslim women whose appearance in social media help set the idea and the practice for sustainable living. Having attracted many housewives to follow their footsteps, existing studies, departing from ecofeminism, have underlined their impactful presence. While an etic evaluation might be pertinent to analyse how much this increasing public role able to improve their stake, an emic reading is no less important to understand their own interpretation. The study argues that a contextual reading of Muslim women's engagement with everyday environmentalism in Indonesia cannot be undertaken by dissuading their view of religiousness, while permeating it with a prescribed gendered analysis provided by ecofeminism. But instead of rejecting the latter, the paper delves into the dynamic interplay of emic and etic rendition to the place of women, environmentalism in everyday life, and religion in Indonesia. Employing ethnography, the study found multiple layers of meaning of religiousness, showing their complicated relation with religious institution and an uneasy alliance with any given feminist ideas.
\end{abstract}

Keywords: everyday environmentalism; Muslim women; Indonesia; emic; etic

\section{Introduction}

During the pandemic, Indonesians witness an increase of interests in practice of sustainable living (SL). Having conducted at individual and collective level, SL is reflected in various practices, including gardening, waste recycling, and voluntary simplicity, to name just a few. Their emergence cannot be isolated from the global cultural turn, which favors a greener lifestyle and finds its breath in a number of green campaigns (Lorenzini, 2019; Hayward \& Roy, 2019). Owing to social media, SL as practice and discourse has reverberated exponentially. In Indonesia, two prominent actors emerge in this excitement are youths (Genevova \& Syahrivar, 2020) and women (Priyatna, Subekti, \& Rahman, 2017).

Compared to the previous type of environmental activism in Indonesia where issues being dealt was "weighty" as it focused on "large-scale environmental damage by destructive forms of production", hence connected to high political economic interests, everyday environmentalism deals with a relatively menial issues pertaining to the "incremental effect of wasteful consumption or small-scale pollution by ordinary citizens" (Fikri \& Colombijn, 16). 
Given the differential in scale, strategy, and objectives, doubt arises on whether the clear moral undertones, which was evident in the previous movement, can still be found in the present type of environmentalism (cf. Fikri \& Colombijn, 2021).

Focusing on Muslim women, the paper attempts to probe into this doubt by contextualizing the normative-based etic interpretation, drawn from ecofeminism (cf. Priyatna, Subekti, \& Rahman, 2017), with empirical-based emic consideration, based on their view of religiousness. Ecofeminism is selected because some Indonesian Muslim scholars, such as Candraningrum (2015) and Ammar (2020) have acknowledged that there is a mutual relation between ecofeminism and Islam. By navigating the dynamic interplay of emic and etic in viewing the place of women, environmental conservation in everyday life, and religion in Indonesia, it is then possible to check on their affect.

\section{Method}

This study employed life-world analytical ethnography (Honer \& Hitzler, 2015), which aims to uncover the life-world of the subjects in a community. Whereas ethnography focus on the individual values or the shared views of a particular culture (von Lehm et al., 2015), the life-world analytical ethnography believed that people are not subject to one particular community, but attached to various - sometimes conflicting - relationship, roles, expectations, and attitudes. In this study, the subjects consist of Muslim urban mothers of 30s to 40s age range with various type of public engagement with respect to the advocation of environmental practice. In order to achieve an "existential engagement" with the subjects, the study applied "observant participation", instead of participant observation, by "reflectively co-experiencing" with the subject (Honer \& Hitzler, 2015). The analysis of this paper centred around the question "what does the environmental activity that you are engaged with mean to you as a Muslim?" The empirical data was then compared with ecofeminist and Islamic view in a reflective analysis (Attia \& Edge, 2017).

\section{Results and Discussussio}

\subsection{Results}

Interaction and discussion with the informants provide an insight on their engaged acts of environmentalism and how it connects them with the roles they have played. Widya, a breastfeeding counsellor, admitted that women, compared to men, have higher tendency to deal with the issue of waste because women consume not only for herself, but also for her family. In terms of breastfeeding,

"We know how good it is, physically and psychologically, for the baby and the mother... and it's environmentally good, as well" (July, 2020).

Meanwhile Mega said that she was motivated to provide a home-based education for her children as she and her husband doubted if public education could break off from the mainstream paradigm, which sustains the dominant system.

"On waste issue alone, I doubt that we can make proper judgment only by being smart, yet numb in feeling. But, ... rather than blaming the system, I realize that it's better to focus on doing what I can... so I tried to accept my part, but instead of making it a personal task, 
I am having it as a family project. Waste issue and waste reduction become our primary project" (February, 2020).

Meanwhile, Gita, also a home-schooler mom, asserted the value of engaged environmental activities in her daily life:

"Routine shapes who I become. Repeated acts on daily basis build my mental and spiritual disposition. That's what I learn and that's what I want to forward to my children..." (March, 2020).

All of them view their presence in everyday acts of environmentalism as part of their role in the family. Being housewives, they tend to be cautious with the issue of waste produced at home, many of which are resulted from meal cooking, washing, and house cleaning that make the list of domestic chores. Hence, it is this attachment to their role as housewives that gives them the responsibility to take up the situation. But, as Mega and Gita implied, women are not the only partaker in this process. Widya also emphasized that all the adult members in the family are equally responsible,

"I'd like to see breastfeeding as an example. The baby is amanah and breastfeeding the baby is fitra... an ecological way of thinking... either way, it works only when the breastfeeding mother has a good support system who equally strive for the same goal" (July, 2020).

Not all of the woman informants gave similar divulgence, though, as some women in the composting and gardening class revealed. Yuni who started her journey to a less waste home said,

"Well, it takes some times to lead an example... even to make the family understand and support what we are practicing. But as long as it is the right thing to do, then it's worth a try, isn't it?" (July, 2020).

In spite of the difference, they all agreed to what Mega said on the value of istiqamah in the action,

"it's not [our job] to make sure if people have really done what we believe is right, but to persistently do what we call upon and show to others, instead... it's what counted" (November, 2020)

\subsection{Discussion}

Based on the statements given by each informant, it is known that they all shared the same view that man and woman carry the same responsibility as God's servants, one of which is to maintain the state of the environment. While they acknowledged that their daily interaction with domestic chores have brought them closer to the issue, hence increased the propensity to take responsibility in dealing with environmental problem at home, such as waste, they basically agree that the action towards SL shall not be placed upon women's shoulders alone. All human, irrespective of gender, are entrusted by the same amanah (trusteeship) to care for the earth. The earth is amanah from God that must be maintained by both man and woman as khalifah (steward of the earth).

Similar to the earth, the family and the household are also seen as amanah to care for. The informants chose to fully embrace the idea of motherhood and family, which is seen as a potential site for social transformation. In Ecofeminism, however, religion, culture, and language are potentially seen as the institution where masculine violence against women, animals, and nature have been legitimized and normalized (Gaard, 2011). As a branch of feminism, ecofeminism also relies on the concept of patriarchal system of domination in 
seeing the connection between the ongoing destruction of natural environment and the subjection of women and other subordinates (Warren, 2000). Hence, while ecofeminism suspects the household as an extension of patriarchal institution, many women who practice SL in everyday life are pivoting their activism from it (cf. Priyatna, Subekti, and Rahman, 2017).

Although Islam-as-interpreted-and-applied in historical context is not immune to patriarchal tendencies, the idea of patriarchy itself is not near to accept by the informants. In fact, they affirm their embracement on Islam as a solution to the many challenges they face in life, while constantly acknowledged their incomprehensive understanding, hence attempting to improve their learning of it. Instead of patriarchy, these women believed that the false conception of fitra (primordial nature) and amanah as the reason why household creates unhealthy relations between husband and wife, parent and children. Speaking about husbandwife relation in a household and the role of parent in a family, Gita said:

"Women hold the key to the many private and public affairs, simultaneously. We conflate the two by role division... as if preparing meals at home lies at the private realm of family, whereas it actually implicated publicly. What mother prepares at home, what father leads an example in the family, those are what make the society" (March 2020).

From this statement, Gita maintained that public/private division as well as father/mother role segmentation in the family cannot be strictly defined. Similar apprehension is also apparent in Mega and Widya who refuse to accept the idea that mothers alone bear the responsibility to raise and nurture the children. Widya's statement on fitra demonstrates that the notion is not equate with the idea of kodrat, whereby the role of women in the family is defined by their biological difference. She asserted that fitra is an ecological framework in Islam to ensure intergenerational justice, in which the wellbeing of mother and children are dependent on the active participation of the father in the family. Mega's insistence to integrate $\mathrm{SL}$ in the home curriculum of the children similarly reflects the same concern.

In its attempt to recover from the condition where women and other subordinates are unequally treated in society, Ecofeminism unravels how interpretation of religious text might distort religious message itself. Reading the Old Testament, Rosemary Radford Ruether (1978) argued that it is hierarchical dualism that justifies the one-dimensional view of human-nature relationship, whereas transcendent dualism naturalizes it. By transcendent dualism, she points to the idea that spirituality, consciousness, and intelligence are superior, whereas the body, which is equated with the root of moral evil, must be tamed, repressed, and subjugated.

While similar idea is also found in Islam, the way it is conceived is somewhat different. Ontologically, man and woman in Islam is not posited as a dual opposition with hierarchical relation. In fact, according to Anwar (2021), despite the difference between secular and religious feminists in Indonesia, their convergence lies on the shared idea that men and women have equal access to spiritual capacity. This is also true for many Muslim women who, like the informants themselves, embrace and support a paternalistic view of maternal values, while espousing the inherent metaphysical equality between men and women as moral agents. Anwar explained that the adoption of these seemingly two contradictory attitudes is quite common in a nation shadowed with colonial experience. Correspondingly, while seeing feminism and all its derivates as a Western product, the informants consider household and family as the true site of cultural change. Moreover, family is amanah that has to be protected for it will be taken into account in the hereafter. This explains why Yuni insists on continuing her effort to lead an example in her family, even when no one supports her cause. Her insistence is based on the premise that each individual, being God's creature and servant, will be charged for the choice made upon the rights and the responsibilities in life. 
Epistemologically, Muslims are compelled to follow a series of ritual, such as daily praying, fasting, and abiding to the stipulated halal/haram food as part of the path to taqwa (piety). Explicitly instructed in the five pillars of Islam, these rituals train every Muslim the necessity of disciplining the body according to the prescribed Islamic rules and how abiding to this regimentation demonstrates one's proof of faith and way to improve spiritually. While Muslim in general regards that believing in a correct Islamic practice and doctrine fosters individual piety, this viewpoint is more pronounced among women (Anwar, 2021). They believe that a repeated practice of bodily behaviour help shapes virtuous attitude and a strong faith, leading to an improved reorientation towards God (Mahmood, 1998), fundamental for achieving a sense of calm and happiness in life (Joshanloo, 2012). Gita's aforementioned statement on the significant value of the routines clearly follows this perspective.

Religion becomes a significant driving force for the informants. When the interview was conducted on November 2020 with Mega, she expressed her disappointment that, compared to issues like polygamy, environment is hardly ever discussed in religious gathering in mosques. Despite this deficiency, she remains taking Islam as her main approach in communicating the issue to the public. While admitting that she is not a religious scholar, she believed that only in religion one can find ethical and moral guidance, hence a solid ground for a sound actualization for many of its adherence. With this in mind, she has compiled environmental messages found in the Quran and the Hadits and published them in a number of children books since 2015. The same approach also applied when she posts in social media and teaches in workshop. Although frequently speaks in Islamic terms, she believed that the message reverberates to anyone, including those of different religious background, who are open for discussion and willing to initiate change by starting from one's self. The doubt that there is little moral undertone in the current type of environmentalism is, therefore, unjustified, partly because of the potential interplay between the issue of social justice, cultural change, and dialogue. Environmental problem not only poses a challenge, but also offers rooms to learn and collaborate.

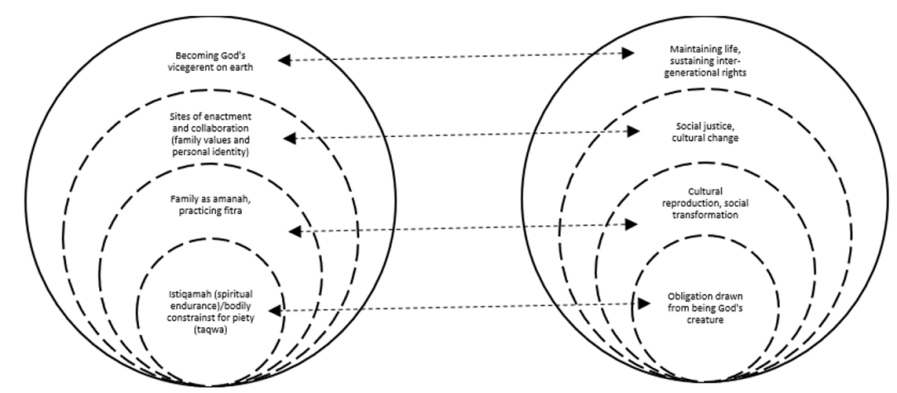

Fig. 1. Life-world analysis of everyday environmentalism among Indonesian Muslim women

\section{Conclusion}

It can be concluded from the discussion that:

1. Muslim women not only participate, but also help constitute the shape and the course of action of everyday environmentalism in Indonesia. While none of the informants have immediate access to policy process, their focus on family as the most innermost circle of influence does not impede them to induce others. 
2. Doubt that there is little moral undertone in the current type of environmentalism is unjustified due to the potential interplay of social justice, cultural change, and dialogue.

3. Despite having complicated relation with religious institution and uneasy alliance with the feminist notion of patriarchy, attempts to re-read and re-interpret religious text and a belief in spiritual equality demonstrates how religion provides cultural context within which these women compose their agentic orientation. Religiousness is, therefore, a crucial feature that needs to be taken into account for further study on environmentalism where women is part.

\section{Reference}

[1] Ammar, N. (2020). 'Are Islamic Thinking and Ecofeminism Possible?', CRCS Wednesday Forum. https://www.crcs.ugm.ac.id/are-islamic-thinking-and-ecofeminismpossible, accessed August $20^{\text {th }}, 2021$.

[2] Anwar, E. (2021). Feminisme Islam di Indonesia: Genealogi, Tantangan, dan Prospek di Indonesia (trans. Genealogy of Islamic Feminism: Pattern and Change in Indonesia by Nina Nurmila). Yogyakarta: Bentang Pustaka.

[3] Attia, M., Edge, Julian. (2017) Be(com)ing a reflexive researcher: a developmental approach to research methodology, Open Review of Educational Research 4 (1), 33-45, DOI: $10.1080 / 23265507.2017 .130006$

[4] Candraningrum, D. (2015). Amanat Al-Insan Dalam Krisis Lingkungan: Kajian Ekofeminisme Islam, Universitas Muhammadiyah Surakarta dan Jurnal Perempuan 3.

[5] Fikri, I., Colombijn, F. (2021). Is Green Islam Going to Support Environmentalism in Indonesia? Anthropology Today 37 (2), 15-18.

[6] Gaard, G. (2011). Ecofeminism Revisited: Rejecting Essentialism and Re-Placing Species in a Material Feminist Environmentalism. Feminist Formations 23 (2) Summer, 26-53. doi: $10.1353 / \mathrm{ff} .2011 .0017$

[7] Genoveva, G., Syahrivar, J. (2020). Green Lifestyles among Indonesian Millenials: A Comparative Study between Asia and Europe. Journal of Environmental Accounting and Management 8 (4), 397-413. DOI:10.5890/JEAM.2020.012.007

[8] Hayward, B., Roy, J. (2019). Sustainable Living: Bridging the North-South Divide in Lifestyles and Consumption Debates. Annual Review of Environment and Resources 44, 157-175. https://doi.org/10.1146/annurev-environ-101718-033119

[9] Honer, A., Hitzler, R. (2015). Life-world Analytical Ethnography: A Phenomenology Based Research Approach. Journal of Contemporary Ethnography 44 (5), 544-562. DOI: $10.1177 / 0891241615588589$

[10] Joshanloo, M. (2012). A Comparison of Western and Islamic Conception of Happiness. Journal of Happiness Studies 14, 1857-1874 (2013). DOI:10.1007/s10902-012-9406-7

[11] Lorenzini, J. (2019). Food Activism and Citizens' Democratic Engagements: What Can We Learn from Market-Based Political Participation? Politics and Governance 7 (4), 131-141. DOI: 10.17645/pag.v7i4.2072

[12] Mahmood, S. (2004). The Politics of Piety. New Jersey: Princeton University Press.

[13] Markham, A.N. (2017). Ethnography in the Digital Era: From Fields to Flow, Descriptions to Interventions. In S. Denzin, Norman K. and Lincoln, Yvonna (Ed.), The Sage Handbook of Qualitative Research, 5th Edition (pp. 650-668). Sage.

[14] Priyatna, A., Subekti, M., Rahman, I. (2017). Ekofeminisme dan Gerakan Perempuan di Bandung. Jurnal Patanjala 9 (3), 439-454. 
[15] Ruether, R.R. (1978). New Women New Earth: Sexist Ideologies and Human Liberation. New York: Seabury Press.

[16] von Lehn, D., Hitzler, R., Honer, A., \& Hitzler, R. (2015). Life-World-Analytical Ethnography: A Phenomenology-Based Research Approach. Journal of Contemporary Ethnography, 44(5), 544-562. https://doi.org/10.1177/0891241615588589

[17] Warren, K.J. (2000). Ecofeminist Philosophy: A Western Perspective on What It Is and Why It Matters. Washington, D.C: Rowman \& Littlefield Publishers, Inc. 